DOI: $10.2478 /$ lpts-2019-0026

\title{
STUDY OF ELECTRICAL PROPERTIES OF BISTABLE SMECTIC-A LIQUID CRYSTAL DISPLAYS
}

\author{
M. Maltisovs ${ }^{1,2}$, D. Pikulins ${ }^{2}$ \\ ${ }^{1}$ HansaMatrix Innovation, 1 Ziedleju Str., Marupe, LV-2167, LATVIA \\ E-mail: matiss.maltisovs@gmail.com \\ ${ }^{2}$ Institute of Radioelectronics, Riga Technical University, \\ 12 Azenes Str., Riga, LV-1048, Latvia \\ E-mail: dmitrijs.pikulins@rtu.lv
}

\begin{abstract}
Bistable smectic-A (SmA) liquid crystal display (LCD) is one of the most promising devices for smart glass applications due to long-term bistability, low haze at clear state, low transmittance at scatter state and low power consumption. The need of a good simulation model for an LCD becomes apparent during the design of driving system. Liquid crystal (LC) capacitance is critical in the simulation of LCD pixels and is voltage dependent due to the crystal characteristics. Bistable smectic-A LC capacitance model is introduced in the paper. The study describes the most relevant conclusions obtained from the measurements of electric properties of bistable SmA LCD samples and electric equivalent circuit characterization.
\end{abstract} smectic- $A$

Keywords: bistable, capacitance model, liquid crystal display,

\section{INTRODUCTION}

Simple parallel RC circuits usually represent the behaviour of liquid crystal displays (LCD) in a variety of situations. These electric circuits are of great practical interest, since they can be used in countless applications ranging from theoretical studies to simulations of LCD elements [1] molecular director axis parallel the surface of the cell.

Due to the anisotropy of LC material, the liquid crystal capacitance $C_{L C}$ is not constant. It varies from a minimum capacitance when no voltage is applied across the LC cell to a maximum capacitance when the LC cell is fully turned on [2]. Thus, the liquid crystal capacitance $C_{L C}$ is bias and time dependent. This mechanism has been thoroughly analysed by some liquid crystal manufacturers and laboratories. However, the formulation is very dependent on the specific liquid crystal type [2], [3]. 
One particular feature of SmA liquid crystals is a marked hysteresis in their switching to the extent that dielectric re-orientation (or other disturbances of the smectic structure) does not relax when the electric field is removed, dielectrically re-oriented SmA liquid crystals remain in the driven state until further forces are applied [4]-[6]. This is explained via reference of the nature of the processes, which are used to drive such liquid crystals [7], [8].

Existing studies do not provide detailed information on bistable SmA LC operational, electrical properties. Contrary to a majority of studies that have been conducted using small samples $<50 \times 50 \mathrm{~mm}$, the present research is based on $300 \times 400 \mathrm{~mm}$ large bistable SmA LC devices. The main goal of the current research is to determine equivalent electric circuit component parameters to simulate a SmA LCD cell, i.e., to create a simulation model which could help in designing a new driving system for SmA LCDs.

\section{EXPERIMENTAL PART}

A total of two different experimental series have been performed. For these experiments, bistable SmA LCDs have been manufactured by EuroLCDs Ltd. (see parameters in Table 1 and Table 2). LCDs have 300x400mm outer dimensions and active area equally divided into 8 pixels (one pixel is $95 \times 275 \mathrm{~mm}$ ), which can be switched individually or as a single unit if they are connected in parallel [9], [10]. To maintain a constant cell gap, $15 \mu \mathrm{m}$ plastic ball spacers with density of $10 \mathrm{pcs} / \mathrm{mm}^{2}$ have been used. LCs have been supplied by Dow Corning Corporation [7], [8].

Previous study on operational properties showed that the working voltage of bistable SmA LCDs was $13 \mathrm{~V} / \mu \mathrm{m}$, clear (transparent or also known as homeotropic) state frequency was $600 \mathrm{~Hz}$ and scatter (light scattering or also known as focal conic) state frequency was $30 \mathrm{~Hz}$ [12].

Table 1

LCD Parameters

\begin{tabular}{|l|c|}
\hline Dimensions & $300 \times 400 \mathrm{~mm}$ \\
\hline Spacer Size & $15 \mu \mathrm{m}$ \\
\hline Liquid Crystal Type & Smectic-A \\
\hline ITO Resistance & $80 \Omega / \mathrm{sq}$ \\
\hline
\end{tabular}

Table 2

LCD Operational Properties

\begin{tabular}{|l|c|}
\hline Driving Voltage & $13 \mathrm{~V} / \mu \mathrm{m}$ \\
\hline Driving Waveform & DC balanced square wave \\
\hline Scatter Frequency & $30 \mathrm{~Hz}$ \\
\hline Clear Frequency & $600 \mathrm{~Hz}$ \\
\hline
\end{tabular}

The LC cell can be considered as an ideal capacitor. Due to its construction, it is very similar to a flat capacitor, where both plates are made up of two indium tin oxide (ITO) layers and between them there is LC material with $\varepsilon_{\mathrm{r}}$ [10]. More precisely is to take into account conductivity loss and LC cell approximation in a narrow band with a non-ideal capacitor model (Fig. 3), where R is the electrical 
resistance of the output (ITO layer and dielectric) and $\mathrm{C}$ is the electrical capacity of a flat capacitor. By adding additional $\mathrm{R}$ and $\mathrm{C}$ elements, a model describing the $\mathrm{LC}$ cell up to a frequency range of $10^{-1}-10^{7} \mathrm{~Hz}$ can be obtained [1], molecular director axis parallel the surface of the cell.

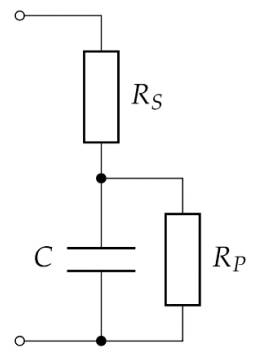

Fig. 1. LC cell equivalent electrical circuit, where $R_{S}-$ ITO layer and dielectric resistance, $C$ - liquid crystal capacitance and $R_{P}-$ liquid crystal resistance.

The first experiment has been devoted to obtaining $R_{S}$ that mainly consists of conducting, transparent layer, ITO resistance measured in ohms per square $(\Omega /$

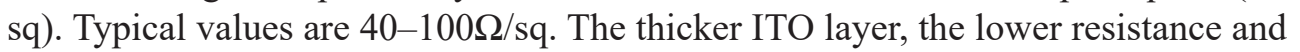
optical transmittance and vice versa. To achieve high optical transmittance and good conductivity, ITO resistance must be chosen between $80-100 \Omega / \mathrm{sq}$. Additionally, ITO layer must be patterned to reduce LC breakdown. ITO must be patterned in strips such that the resistance of the strips would increase, thus lowering the current in the series. The great benefit of using patterned electrode is that the overall resistance of the cell does not change, and the capacitive charging times of the cell are not affected. Unfortunately, the patterning is visible to the eye since it scatters light. Compromise between the optical quality and electrical properties should be found [11], [13]. Bistable displays, in which an altering field at different frequencies is used for switching from clear to scattering states and vice versa, require electric fields at around $10 \mathrm{~V} / \mu \mathrm{m}$ for operation. When operated at such high voltages an electrical breakdown is very likely to occur in the liquid crystal (LC).

Equivalent series resistance $R_{S}$ (Eq. 1) can be determined by rapidly applying voltage and measuring the voltage on a series-connected resistor ( $R_{x}=5-10 \Omega$ (see Figs. 2 and 3). At the first moment of time $C$ is a short circuit and a voltage divider is formed.

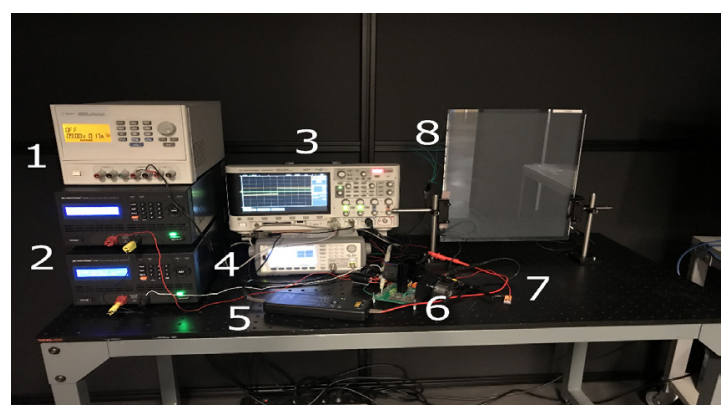

Fig. 2. Overview of the experimental setup used for measuring electrical properties of bistable smectic-A liquid crystal displays. Used equipment: 1 - Agilent U8032A, 2 - B\&K Precision 9184, 3 - Agilent DSOX2014A, 4 - Agilent 33500B, 5 - Tektronix P5200, 6 - Apex PA93, 7 - $R_{x}$, 8 - bistable smectic-A liquid crystal display. 


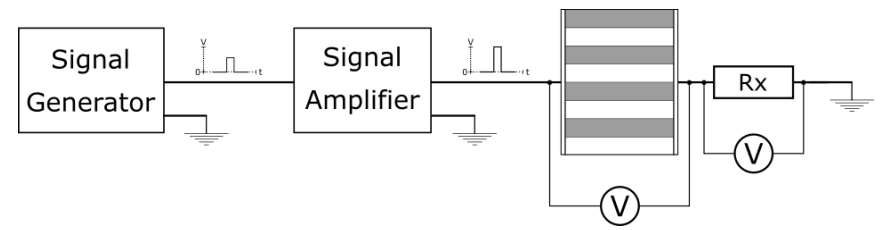

Fig. 3. Simplified functional schematic of electrical parameter measurement setup, where waveform generator generates short 100us square wave impulse, signal amplifier amplifies impulse up to $\pm 190 \mathrm{~V}$ and outputs signal to bistable smectic-A liquid crystal display and additional resistance.

$R_{S}$ can be calculated as follows:

$$
R_{S}=\frac{\left(V_{S}-V_{x}\right) R_{x}}{V_{x}} .
$$

An effect related to the reorientation experienced by the LC molecules is the change of the capacitance offered by a single LC pixel, $C_{L C}$. This capacitance depends on the applied voltage because of the dielectric anisotropy of the LC mixture [10].

In the second experiment, the circuit shown in Fig. 4 is used to determine equivalent parallel resistance $R_{P}$ and capacitance $C$. In this case $V_{S}$ is not a rapid voltage step but more gradual and $R_{x}=1 k \Omega$ (Eq. 2) [14]:

$$
\frac{V_{x}(t)}{R_{x}}=I_{R_{x}}(t)=I_{C}(t)+I_{R_{P}}(t)
$$

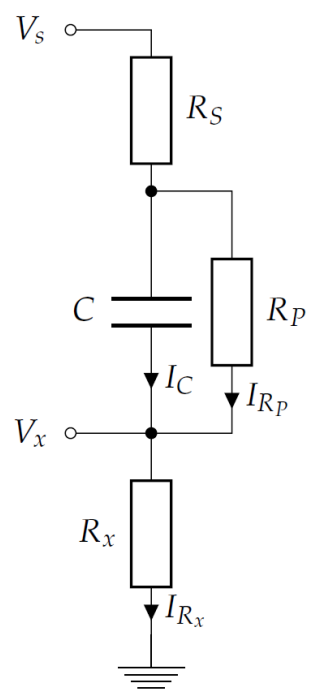

Fig. 4. Electrical schematic of electrical parameter measurement circuit, where $V_{s}-$ voltage applied to LCD, $R_{S}, R_{p}$ and $C$ - liquid crystal display (see Fig. 1 for detailed parameter descriptions), $V_{x}$ - measured voltage on LCD, $R_{x}$ - additional resistance.

After certain amount of time $C$ is fully charged, $I_{C}=0$ and $I_{R_{x}}=I_{R_{P}}$. Since $R_{S} \ll R_{x}, R_{P}$, then $R_{P}$ can be calculated according to the voltage divider formula (Eq. 1). 
When $R_{P}$ is found $I_{C}$ can be calculated as follows:

$I_{C}(t)=I_{R_{x}}(t)=I_{R_{x}}(t)-I_{R_{P}}(t)=\frac{V_{x}(t)}{R_{x}}-\frac{V_{s}-V_{x}(t)}{R_{P}}$.

Total charge accumulated on the capacitor can be obtained by integrating $I_{C}(t)$ :

$Q_{C}=\int I_{C}(t) d t$

Fully charged equivalent capacitor capacity can be calculated as follows:

$$
C=\frac{Q_{C}}{V_{s}-V_{x}}
$$

An LC with high viscosity needs high electric field for operation. In large electric fields, electrical breakdown is likely to occur. Electrical breakdown in the cell is observed when the electric field intensity $E$ in the LC layer is above a specific breakdown value $E_{b r}$. The $E_{b r}$ is governed by the conductivity of the liquid crystal, surface smoothness of the electrodes, defects in coatings as well as point defects, such as dust particles, in the LC layer. The dielectric breakdown in an LC cell is a complicated process discussed elsewhere [15]. Based on the parameters of the equivalent electrical circuit, it is possible to calculate power dissipation on $R_{S}$ and $R_{P}$ :

$$
\begin{aligned}
& R_{P}(t)=I_{x}^{2}(t) \cdot R_{S}=R_{S} \cdot \frac{V_{x}^{2}(t)}{R_{x}^{2}} \\
& P_{R}(t)=\frac{U_{C}^{2}(t)}{R p}=\frac{\left(V_{S}(t)-V_{x}(t) \cdot\left(1+\frac{R_{S}}{R_{x}}\right)\right)^{2}}{R_{P}} .
\end{aligned}
$$

\section{RESULTS AND DISCUSSION}

The results obtained for the measurements of equivalent series resistance $R_{S}$ are shown in Fig. 5. Two different $R_{x}$ values were used $(5.2 \Omega, 10.4 \Omega)$. The measurements were made at several $V_{S}$ values ranging from $5 \mathrm{~V}$ to $195 \mathrm{~V}$ with $5 \mathrm{~V}$ increment step. Blue dots represent $R_{x}=5.2 \Omega$ and orange dots $-R_{x}=10.4 \Omega$. The green line represents the mean value of both $R_{x}$ value measurement data. Pronounced deviation is noticeable in $5 \mathrm{~V}$ to $30 \mathrm{~V}$ range. When the LC cell is energized, switching is gradually taking place. This is due to the low rotational force caused by the electric field applied to liquid crystal molecules if they are in the lowest energy state. From $40 \mathrm{~V}$ to $195 \mathrm{~V} R_{S}$ does not depend on the applied voltage and $R_{S} \approx 71 \Omega$. 


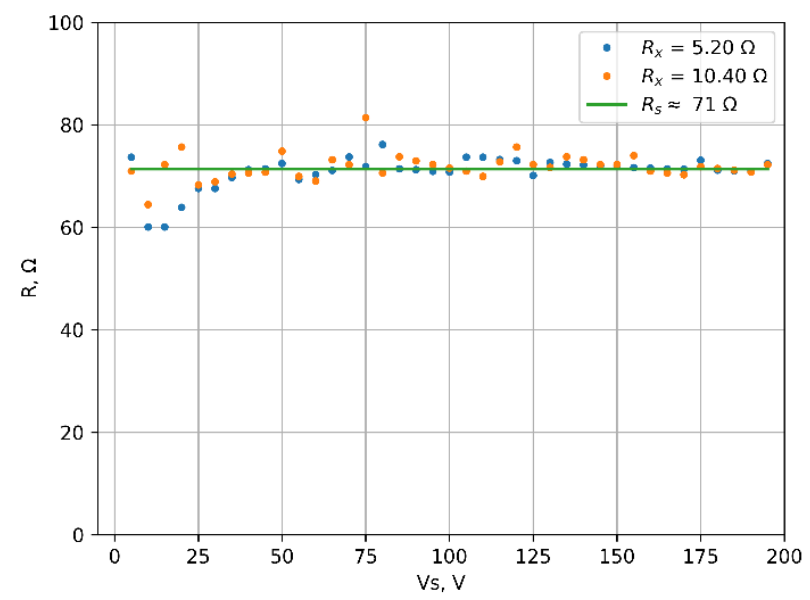

Fig. 5. Equivalent series resistance $R_{S}$ dependence of $V_{S}$, with $R_{x}-5.2 \Omega$ and $10.4 \Omega$ over $5 \mathrm{~V}-195 \mathrm{~V}$ range with $5 \mathrm{~V}$ increment step. Green line - mean value of both $R_{x}$ value measurement data, $R_{S} \approx 71 \Omega$.

The results obtained for the measurements of equivalent parallel resistance $R_{P}$ are shown in Fig. 6. Dotted blue line represents measured $R_{P}$ and the orange line - the calculated mean value of $R_{P}$ in LCD working range of $100 \mathrm{~V}-195 \mathrm{~V}$. From $5 \mathrm{~V}$ to $20 \mathrm{~V}$, there is an increase in resistance as it should be with different LC materials (for example, cholesteric LC) were $R_{P}$ increases up to $1 M \Omega$. In this case, a rapid decrease follows, and parallel resistance decreases to $\approx 13.5 \mathrm{k} \Omega$ and from $125 \mathrm{~V}$ to $195 \mathrm{~V}$ stays within $5 \%$ deviation. Low resistance is explained by the difference of the liquid crystal composition itself.

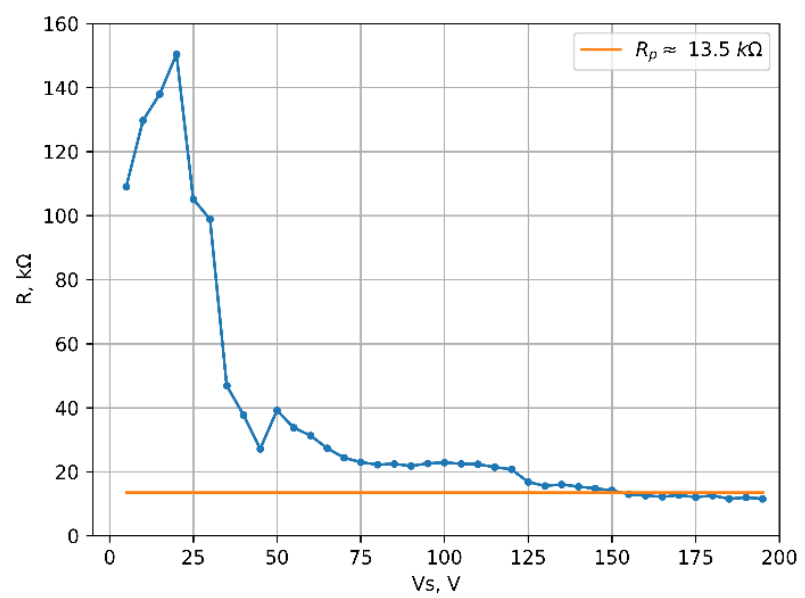

Fig. 6. Equivalent parallel resistance $R_{P}$ dependence of $V_{S}$, with $R_{x}-1 \mathrm{k} \Omega$ and over $5 \mathrm{~V}-195 \mathrm{~V}$ range with $5 \mathrm{~V}$ increment step. Orange line - mean value of $R_{P}$ in LCD working range of $100 \mathrm{~V}-195 \mathrm{~V}$,

$$
R_{p} \approx 13.5 k \Omega \text {. }
$$

Measured LCD $C$ capacitance changes over $5 \mathrm{~V}$ to $195 \mathrm{~V}$ range of $V_{s}$ (see Fig. 7). Dotted blue line represents $C$ and the orange line - a mean value of $C$ in LCD working range of $100 \mathrm{~V}-195 \mathrm{~V}$. Measured capacitance from $5 \mathrm{~V}$ to $45 \mathrm{~V}$ $C \approx 0.044 \mu F$ with a slight drop at $35 \mathrm{~V}$. Then, increasing $V_{s}$, the capacitance increases 
to $100 \mathrm{~V}$ and $C \approx 0.053 \mu \mathrm{F}$. Continuing increasing the voltage capacitance, the value changes within $10 \%$ range. Liquid crystal material dielectric permeability depends on the position of the molecules and can be influenced by the external electric field; $C$ also depends on the applied electric field and it is not linear.

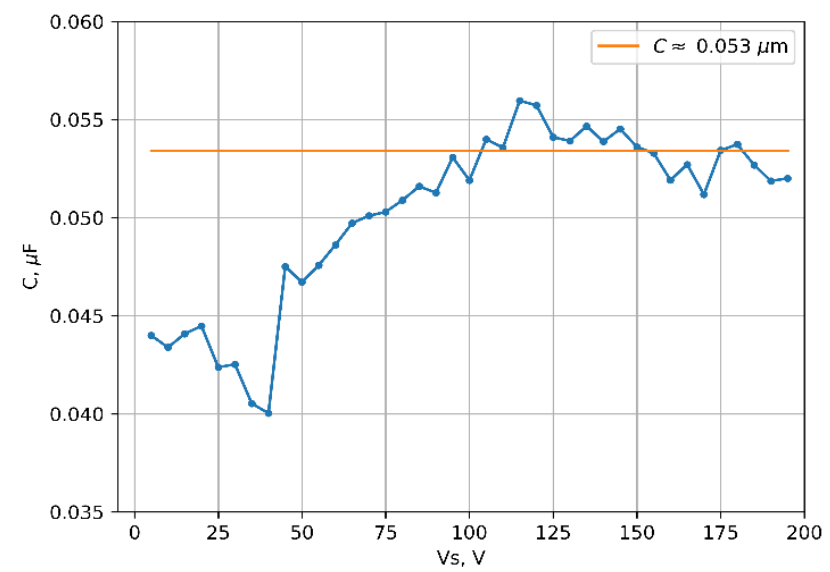

Fig. 7. LCD cell capacitance $C$ dependence of $V_{S}$, with $R_{x}-1 \mathrm{k} \Omega$ and over $5 \mathrm{~V}-195 \mathrm{~V}$ range with $5 \mathrm{~V}$ increment step. Orange line - a mean value of $C$ in LCD working range of $100 \mathrm{~V}-195 \mathrm{~V}, C \approx 0.053 \mu F$.

The obtained power dissipation results on $R_{S}$ and $R_{P}$ are shown in Fig. 8. Dotted orange line represents $R_{P}$ and dotted blue line $-R_{S}$ resistance. At $195 \mathrm{~V} V_{S}$, which is the typical operational voltage of used LCD samples, $R_{S} \approx 2.1 \mathrm{~W}$ and $R_{P} \approx 6.3 W$. Both the equivalent parallel and series resistance show exponential growth. Most of the power is dissipated on $R_{P}$. $R_{P}$ can be reduced by minimising voltage; however, this would affect the LCD switching speeds and optical parameters. $R_{S}$ cannot be reduced due to the proportional current required by the LCD to charge its equivalent capacity.

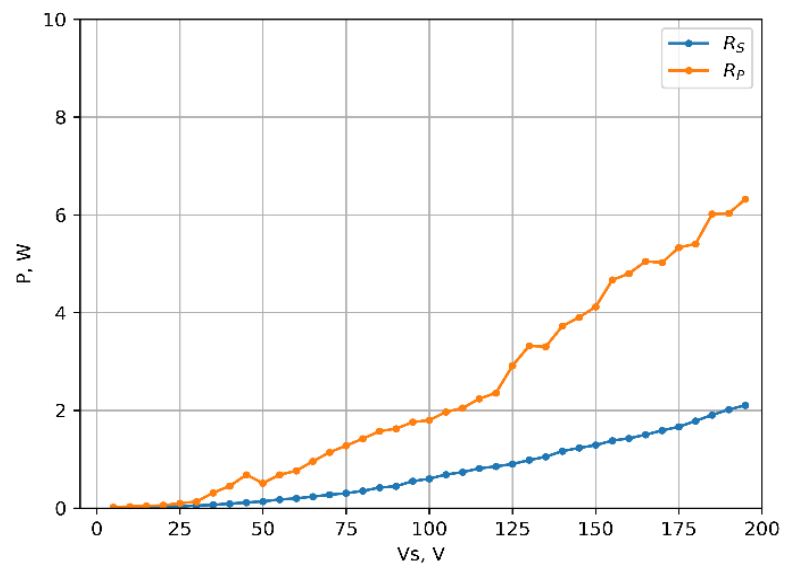

Fig. 8. $R_{S}$ and $R_{P}$ power dissipation dependence of $V_{S}$, with $R_{x}-1 \mathrm{k} \Omega$ and over $5 \mathrm{~V}-195 \mathrm{~V}$ range with $5 \mathrm{~V}$ increment step. Dissipated power at LCD operational voltage $195 \mathrm{~V}$ (see Table 2) - Blue line: $R_{S} \approx 2.1 \mathrm{~W}$, orange line: $R_{P} \approx 6.3 \mathrm{~W}$. 


\section{CONCLUSIONS}

1. The experimentally obtained dependence of equivalent series, parallel resistance and bistable smectic-A capacity on applied control voltage has been presented in the paper.

2. The equivalent series $R_{S}$ and parallel resistance $R_{P}$ studies show that $R_{S}$ stays within manufacturers' provided ITO tolerances and do not depend on applied voltage. $R_{P}$ resistance is much lower compared to other LCD parallel resistance with different LC materials (for example, cholesteric LC).

3. Capacitance $C$ measurements give information about LCDs working range $100 \mathrm{~V}-195 \mathrm{~V}$, at which the applied electric field is high enough to be able to rotate LC molecules and change LCD state from transparent to scattering and vice versa. Additional in-depth research should be done in $5 \mathrm{~V}-95 \mathrm{~V}$ range to fully understand LC molecule threshold voltage at which they start to rotate.

4. Great attention should be paid to power dissipation because with such a low internal parallel resistance LC can quickly reach its temperature limit and LCD will stop working.

5. Simulation model parameters $R_{S}=71 \Omega, R_{P}=13 \mathrm{k} \Omega, C=53 \mathrm{nF}$ will provide sufficient information about electric functionality of large size $300 x 400 \mathrm{~mm}$ bistable smectic-A liquid crystal displays and can be integrated into the development of larger systems.

Further research will be focused on additional experiments with bistable smectic-Aliquid crystal displays due to unknown behaviour in long-term functionality, long-term switching tests to understand degradation boundaries for LC and LCD, driving waveform impact on the power consumption and optical parameters, etc.

\section{REFERENCES}

1. Aoki, H. (1996). Dynamic characterization of a-Si TFT-LCD pixels. IEEE Transactions on Electron Devices, 43(1), 31-39. https://doi.org/10.1109/16.477590

2. Bahadur, B. (1990). Liquid crystals - applications and uses (vol. 1). Canada: Litton Systems Canada. https://doi.org/https://doi.org/10.1142/1013

3. Choi, T.-H., Do, S.-M., Jeon, B.-G., \& Yoon, T.-H. (2019). Low-power control of haze using a liquid-crystal phase-grating device with two-dimensional polymer walls. Optics Express, 27(3), 3014. https://doi.org/10.1364/oe.27.003014

4. Clapp, T. V., Crossland, W. A., Davey, A. B., Grassman, M., Hannington, J. P., King, R. K., ... Xu, H. (2011). Liquid crystal formulations and structures for smectic a optical devices. Retrieved from http://www.dowcorning.com/content/paintink/paintinkresin/ default.aspx

5. Costa, M. R., Altafim, R. A. C., \& Mammana, A. P. (2006). Electrical modeling of liquid crystal displays-LCDs. IEEE Transactions on Dielectrics and Electrical Insulation, 13(1), 204-209. https://doi.org/10.1109/TDEI.2006.1593418

6. Cristaldi, D. J. R., Pennisi, S., \& Pulvirenti, F. (2009). Liquid Crystal Display Drivers. Techniques and Circuits. Springer Netherlands. https://doi.org/10.1007/978-90-481$2255-4$ 
7. Gotlaufs, R. (2018). Electrically Controllable Optical Diffusers and Development of an Improved Electrical Drive Circuit. Riga: Riga Technical University.

8. Hannington, J. P., Clapp, T. V., Nishida, F., King, R. K., Farooq, O., Grassman, M., ... Pivnenko, M. (2013). Oligosiloxane modified liquid crystal formulations and devices using same (US Patent).

9. Huh, J. W., Ji, S. M., Heo, J., Yu, B. H., \& Yoon, T. H. (2016). Bistable light shutter using dye-doped cholesteric liquid crystals driven with crossed patterned electrodes. Journal of Display Technology, 12(8), 779-783. https://doi.org/10.1109/JDT.2016.2537827

10. Karmakar, G., Roy, S., Chattopadhyay, G., \& Xiao, Z. (2017). Dynamically controlling exterior and interior window coverings through IoT for environmental friendly smart homes. Proceedings - 2017 IEEE International Conference on Mechatronics, ICM 2017, 487-491. https://doi.org/10.1109/ICMECH.2017.7921156

11. Lan, Z., Li, Y., Dai, H., \& Luo, D. (2017). Bistable smart window based on ionic liquid doped cholesteric liquid crystal. IEEE Photonics Journal, 9(1). https://doi.org/10.1109/ JPHOT.2017.2653862

12. Lueder, E. (2010). Liquid crystal displays: Addressing schemes and electro-optical effects (2nd ed.). Wiley. Retrieved from https://www.wiley.com/en-lv/Liquid+Crystal+ Displays $\% 3 \mathrm{~A}+$ Addressing+Schemes+and+Electro+Optical+Effects $\% 2 \mathrm{C}+2$ nd+Editionp-9780470688182

13. Maltisovs, M., Krumins, K., Ozols, A., \& Pikulins, D. (2018). Study of the operational properties of bistable smectic-a liquid crystal displays. Latvian Journal of Physics and Technical Sciences, 55(3), 54-62. https://doi.org/10.2478/lpts-2018-0021

14. Mozolevskis, G., Ozols, A., Nitiss, E., Linina, E., Tokmakov, A., \& Rutkis, M. (2015). Reduction of electric breakdown voltage in LC switching shutters. Latvian Journal of Physics and Technical Sciences, 52(5), 47-57. https://doi.org/10.1515/lpts-2015-0028

15. Neusel, C., \& Schneider, G. A. (2014). Size-dependence of the dielectric breakdown strength from nano- to millimeter scale. Journal of Mechanics and Physics of Solids, 63, 201-213. https://doi.org/10.1016/j.jmps.2013.09.009

\title{
BISTABILO SMECTIC-A ŠKIDRO KRISTĀLU DISPLEJU ELEKTRISKO PARAMETRU IZPĒTE
}

\author{
M. Maltisovs, D. Pikuḷins
}

Kopsavi $1 \mathrm{kums}$

Bistabilie Smectic-A (SmA) LCD ir viena no daudzsološākajām tehnoloğijām gudro stiklu produktu izstrādei, pateicoties ilgstošai bistabilitātei, augstai gaismas caurlaidībai caurspīdīgā stāvoklī, zemai gaismas caurlaidībai gaismu izkliedējošā stāvoklī un zemajiem energoresursu patēriņiem. Vajadzība pēc laba škidrā kristāla simulācijas modeḷa parādās vadības sistēmas izstrādes laikā. Škidro kristālu (LC) kapacitāte ir kritiska LCD pikseḷu simulēšanā un ir atkarīga no sprieguma šķidrā kristāla īpašību dēḷ. Pētījuma ietvaros tika veikti šķidro kristālu displeju virknes, paralēlo pretestību, kapacitātes un jaudas mērījumi. Izdarīti secinājumi par iegūtajiem rezultātiem, izteikti priekšlikumi turpmākajiem pētījumiem.

17.10.2019. 